This document is the accepted manuscript version of the following article:

Seim, A., Treydte, K., Trouet, V., Frank, D., Fonti, P., Tege1, W., ... Büntgen, U. (2015). Climate sensitivity of Mediterranean pine growth reveals distinct east-west dipole. International Journal of Climatology, 35(9), 2503-2513. https://doi.org/10.1002/joc. 4137

Climate sensitivity of Mediterranean pine growth reveals distinct east-west dipole

Andrea Seim ${ }^{1,2 *}$, Kerstin Treydte ${ }^{2}$, Valerie Trouet $^{3}$, David Frank ${ }^{2,4}$, Patrick Fonti ${ }^{2}$, Willy

Tegel $^{5}$, Momchil Panayotov ${ }^{6}$, Laura Fernández Donado ${ }^{7,8}$, Paul Krusic $^{9}$, \& Ulf Büntgen ${ }^{2,4}$

${ }^{1}$ Regional Climate Group, Department of Earth Sciences, University of Gothenburg, 40530 Gothenburg, Sweden

${ }^{2}$ Swiss Federal Research Institute, WSL, Zurcherstrasse 111, 8903 Birmensdorf, Switzerland

${ }^{4}$ Oeschger Centre for Climate Change Research, Bern, Switzerland and Global Change

\title{
Andrea Seim
}

E-mail: andrea.seim@gvc.gu.se 


\section{Abstract}

The European Mediterranean region is governed by a characteristic climate of summer drought that is likely to increase in duration and intensity under predicted climate change. However, large-scale network analyses investigating spatial aspects of pre-instrumental drought variability for this biogeographic zone are still scarce. Here, we introduce 54 mid to high-elevation tree-ring width (TRW) chronologies comprising 2186 individual measurements from pine trees (Pinus spp.). This compilation spans a $4000 \mathrm{~km}$ east-west transect from Spain to Turkey, and was subjected to quality control and standardization prior to the development of site chronologies. A principal component analysis (PCA) was applied to identify spatial growth patterns within the network's common period 1862-1976, and new composite TRW chronologies were subsequently developed and investigated. The PCA reveals a common variance of only $19.7 \%$ over the 54 pine chronologies from the same biogeographic zone. More interestingly, a dipole pattern in growth variability is found between the western (15\% explained variances) and eastern $(9.6 \%)$ sites, persisting back to 1330 AD. While pine growth on the Iberian Peninsula and Italy favors warm early growing seasons, summer drought is most critical for ring width formation across the eastern Mediterranean. Synoptic climate dynamics have been identified as the driving mechanism of a distinct east-west dipole in the growth variability of Mediterranean pines, which have been in operation at least for the last seven centuries. 
Keywords

Climate dynamics, Dendroclimatology, Drought response, Mediterranean East-West dipole, Palaeoclimatology, Pinus spp., Principal Component Analysis, Tree-ring width

Running title: East-west dipole in climate sensitivity of Mediterranean pines

\section{Introduction}

The European Mediterranean region represents a unique climatic zone where drought-prone ecosystems have developed under strong environmental constraints including perpetual summer drying and extensive settlement pressure. Projected global warming will likely have an impact on the hydrological cycle in this region (IPCC, 2013). General circulation models forecast a decrease in precipitation and increase in temperature, together with an increase in the frequency and severity of weather extremes such as floods and heat waves (Gao and Giorgi, 2008). To facilitate accurate future climate scenarios and related ecological implications for this region, quantitative information about pre-industrial climate conditions, derived from proxy climate records, is needed.

Predicting future climate scenarios for the Mediterranean region is challenging because climatic fluctuations exhibit a high degree of spatial variability due to the complex interaction of synoptic modes (Dünkeloh and Jacobeit, 2003). This complexity is mainly governed by meridional climatic differences representing the transition from the temperate zone in the north to the subtropics in the south. The land-sea distribution and significant orographic features also influence local climatic conditions. Numerous investigations based upon

71 instrumental climate and re-analyses data, especially for the winter season, have provided an improved understanding of regional climate differences in the Mediterranean Basin. However, these studies are largely restricted to the last 50 years (e.g., Xoplaki et al., 2003; Sousa et al., 
2011) and only a limited number of annually resolved climate proxy data is available to extend this record further back in time (see Luterbacher et al., 2012 for a review).

Tree-ring width (TRW) chronologies are the most prevalent of these proxy data, are characterized by a broad spatial availability, and offer the possibility to cover most of the last millennium at annual resolution. The pine genus (Pinus spp.) is a native, long-lived, ubiquitous component of the Mediterranean flora (Barbéro et al., 1998) and enables the development of well-replicated and dense networks over large spatial and long temporal scales. Pine trees are of particular interest because they exhibit a large ecological amplitude and various adaptation strategies and form natural forest stands up to timber line in the Mediterranean Basin. So far, the majority of conducted dendroclimatological studies using Mediterranean trees have largely been restricted to either local scales (e.g. Büntgen et al., 2010a; Seim et al., 2012), occasionally to sub-regional scales (e.g. Richter et al., 1991; Hughes et al., 2001; Touchan et al., 2014) or to one single species at larger scale (de Luis et $a l ., 2013)$. The only spatial field reconstruction for the Mediterranean was developed by Nicault et al. (2008) and addresses summer drought variability in a multi-species network over the past 500 years.

Here, we evaluate the growth-climate response of a substantial collection of 54 pine TRW site chronologies from mid- to high-elevations in the Mediterranean Basin. Regional growth patterns were identified using Principal Component Analysis (PCA) for the common period 1862-1976. New composite TRW chronologies were developed for three main and five subregions that were compared, assessed, and discussed with respect to possible causes for regional pine growth variability, prevailing synoptic climate forcing, and the potential for future drought reconstructions.

\section{Data and methods}

\subsection{Network establishment}


100 We compiled a network of 2186 TRW series from 54 pine sites across the Mediterranean

101 region (Figure 1 and Table S1, Supporting Information). Only chronologies spanning more 102 than 200 years, with an inter-series correlation (Rbar) above 0.45, were considered (Table S1,

103 Supporting Information). In total, 13 TRW chronologies were contributed by the authors, 39

104 TRW chronologies were selected from the ITRDB (International Tree-Ring Data Bank, 105 http://www.ncdc.noaa.gov/paleo/treering.html, Grissino-Mayer and Fritts, 1997), and two 106 chronologies, one from Greece and one from Italy, were kindly provided by P.I. Kuniholm 107 and L. Todaro, respectively. The genus composition in this pine network includes $P$. 108 halepensis var. brutia Hen., $P$. heldreichii Christ plus $P$. heldreichii var. leucodermis Ant., $P$. 109 mugo Turra, $P$. nigra Arn., $P$. sylvestris L., and P. mugo spp. uncinata (Ramond) Domin.

110 Cross-dating of all TRW series was first visually checked and then statistically verified using 111 the program COFECHA (Holmes, 1983). To preserve growth variation on inter-annual to 112 multi-decadal time-scales, age-related growth trends were removed from all individual TRW 113 series using 150-year cubic smoothing splines (150yr SPL) after power transformation (PT)

114 (Cook and Peters, 1997), via the application of the program ARSTAN (Cook and Krusic, 115 2010). TRW chronologies were truncated at a minimum of five series. The robustness of the 116 chronologies was evaluated by the Expressed Population Signal (EPS; Wigley et al., 1984), 117 which was calculated over 50-year periods with 25 years of overlap.

\subsection{Instrumental data}

120 A high-resolution $\left(0.5^{\circ} \times 0.5^{\circ}\right)$ monthly resolved dataset of gridded climate indices (CRU

121 TS3.1; Mitchell and Jones, 2005) was used to assess the climate sensitivity of the individual 122 site chronologies. Temperature, precipitation and drought (scPDSI; van der Schrier, 2006) anomalies, with respect to their 1961-1990 averages, were calculated for the period 1901-

1242002 for each grid point closest to the TRW sites (Figure 1a). In a later step, the climate 125 variables from individual grid points were averaged in correspondence with the outcome of 
the PCA (see chapter 2.3). In our correlation analysis we used 31 grid boxes of temperature

127 and precipitation data, and 30 grid boxes of scPDSI data because the latter were only

128 available north of $35^{\circ} \mathrm{N}$. The grand means of all Rbar values of annual temperature,

129 precipitation, and scPDSI data across the network are $0.57(\mathrm{p}<0.001), 0.21(\mathrm{p}<0.05)$, and

$130 \quad 0.26(\mathrm{p}<0.05)$ respectively, indicating comparable temperature but heterogeneous moisture

131 conditions across the region. Pearson's correlation coefficients were calculated between TRW

132 records and means of monthly temperature, scPDSI, and sums of monthly precipitation, using

133 an 18-month window from previous year's May to current October. Spatial correlations with

134 CRU TS3.1 data were calculated and plotted using the KNMI Climate Explorer

135 (http://climexp.knmi.nl; van Oldenborgh and Burgers, 2005; Trouet and van Oldenborgh,

136 2013).

\subsection{Spatial analyses}

139 We applied a PCA (Peters et al., 1981) including 54 TRW site chronologies in order to

140 identify systematic growth patterns inherent to the pine network over 1862-1976 common

141 period. All principal components (PCs) with eigenvalues greater than one were retained for

142 further analysis. The first PC was used to determine the primary climatic driver of common

143 variance. Loadings along the second and third PC axes served as the basis for regional

144 subdivision resulting in three main groups. This procedure was repeated using chronologies

145 categorized by PC2 and PC3, which resulted in five additional subgroups (all labeled with

146 respect to the PCA outcome as seen in Figure 3a). Composite chronologies were developed

147 for the eight network groupings by averaging the individual TRW series of all sites in a

148 group. Hierarchical cluster analysis (Ludwig and Reynolds, 1988) over the same common

149 period was conducted to verify the PCA outcome (Figure S1, Supporting Information).

150 Potential differences and similarities in the temporal variability of the two main groups were

151 investigated on the basis of 20-year high- and low-pass filtered composite TRW records. 
152 Additionally, extreme years in year-to-year variability were defined as years when the

153 absolute value of the high-pass filtered TRW records exceeded the 1.5 standard deviation.

154 To evaluate the spatial decay in intra- and inter-species signal strength, correlations were

155 computed as a function of distance between all sites in the network (54 TRW and 31 climatic 156 grid points) for the 1862-1976 (TRW) and 1901-1976 (climate) periods. The same approach

157 was used for temperature and precipitation grid point data for winter (previous year December 158 to current year February, DJF) and summer (June to August, JJA).

159 Finally, factors influencing tree growth were analyzed using cross-correlations including 160 climatic and geographic aspects, as well as species and site chronology characteristics.

\section{Results}

\subsection{Network characteristics and regionalization}

164 The maximum and minimum length of the chronologies after truncation $\mathrm{n}(\mathrm{i})<5$ series is 1041 years (968-2008; Lura, Albania) and 142 years (1862-2003; Scotida Forest, Greece), (Figure

2 and Table S1, Supporting Information). The mean segment length (MSL) of all

167 chronologies is 345 years after truncation. The number of samples per site varies from 11

168 (Troodos Mountain, Cyprus) to 200 (Gerber, Spain) with a mean of 41 (see Table S1,

169 Supporting Information). The first 6 PCs (eigenvalue >1) of the entire network explain $62 \%$

170 of the total common variance (Figure 3). Similar results were obtained for the pre-whitened

171 residuals (not shown), but we used standardized residuals throughout the experiment. The first

172 PC alone (herein referred to as Med.) explains $19.7 \%$ of the common variance over the entire

173 pine network. The network can be divided in three geographically distinct regions based on

174 PC2 (representing 15\% of the total variance): sites in the western Mediterranean region (Med.

175 West) have negative loadings on PC2 (-0.57 to -0.09 ; Figure 3$)$, whereas sites in the eastern

176 Mediterranean region (Med. East) have positive loadings (0.15 - 0.66). Sites in Italy have PC2

177 loadings close to zero $(-0.08-0.08)$ contributing to a third geographical group. 
178 The Med West group consists of 32 site chronologies and the first three axes of a separate

179 PCA of these 32 chronologies cumulatively explain $51.5 \%$ of their total variance. The first 180 axis explains $29.5 \%$ common variance and all series have positive scores ranging from 0.3 181 (Pic d'Anie, France) to 0.8 (Guadarrama, Loma de Noruego, Spain). The Med. West group 182 can be subdivided based on PC2 (13.7\%) representing chronologies from central Spain (Med.

183 W1, 18 chronologies) and from the Pyrenees (Med. W2, 10 chronologies; Figure 3).

184 The first three PCs of the Med. East (22 chronologies) explain a slightly higher amount of 185 total common variance $(63.6 \%)$ with the first axis explaining $39.7 \%$ common variance and 186 positively loading scores ranging from 0.4 (Kozlu Pinari, Turkey) to 0.8 (Kirazli, Aligalani, 187 Atalani, Turkey). Based on PC2 (15.8\% common variance), two subgroups can be 188 distinguished: Turkey and Cyprus (Med. E1) and the Southern Balkans (Med. E2).

189 Based on the PC analyses, regional composite TRW chronologies were developed by 190 aggregating the corresponding individual TRW series. All relevant statistics for the three 191 regional groups and the five regional subgroups are shown in Table 1. Hierarchical cluster 192 analysis revealed similar results by splitting the TRW network in 5 sub-groups including an 193 individual Italian group (Figure S1, Supporting Information).

194 The temporal coherency analysis between the detrended composite TRW chronologies Med. 195 West and Med. East revealed limited common variability $(r=0.1, \mathrm{p}>0.1)$ over the well196 replicated ( $\mathrm{n}>800$ series) and robust 1330-2008 period (Figures $4 \mathrm{a}$ and 4b). This low 197 coherence is confirmed in both the low and high frequency domains over three 338/339-year 198 long correlation periods (1330-1669, 1500-1838 and 1669-2008) (Figure 4).

199 Moreover, out of 42/46 positive/negative extreme years for West and 55/46 positive/negative 200 extremes for East, only nine positive $(1411,1452,1499,1541,1590,1846,1885,1914,1959)$ 201 and five negative $(1602,1725,1806,1880,1909)$ extreme years are in common. An 202 association between the extreme years calculated for the West and East group is not evident at 203 the $95 \%$ significance level $(P=0.384)$. The 14 common extreme years are also extremes in 
204 the Med. chronology (PC1). From the total of 49/50 positive/negative extreme years for this chronology, 10/12 positive/negative extreme years are unique for the Mediterranean as a whole.

\subsection{Spatial characteristics}

209 Correlations of the 54 TRW chronologies as a function of species and distance, for the common period 1862-1976, are shown in Figure S2 (Supporting Information). The total number of pairs used in the intra-species curve is 583 and for the inter-species is 2239 . The highest positive intra-species correlation is $r=0.58(\mathrm{p}<0.001)$ for neighboring sites, i.e., 65 chronology pairs within a range of $50 \mathrm{~km}$ (Figure S2a, Supporting Information). This association remains significant for up to $1500 \mathrm{~km}$ with a mean correlation coefficient of $r=$ $0.38(\mathrm{p}<0.001)$ despite the decreasing number of correlation pairs (average $n=15)$. Interspecies correlation results are similar to those for the same species despite higher replication levels (Figure S2b, Supporting Information). The highest positive correlation found is $r=0.41$ in the first $50 \mathrm{~km}$ with a replication of 38 chronology pairs. Between 1700 and $3400 \mathrm{~km}$ the correlation coefficients settle around zero increasing slightly afterwards. The correlation decay length for both the inter- and intra-species results can be expressed using a second degree polynomial fit, with higher explained variance for the intra-species assembly $\left(R^{2}=\right.$ $0.56, \mathrm{p}<0.01)$ than for the inter-species one $\left(R^{2}=0.23, \mathrm{p}<0.05\right)$.

The corresponding climate data offer 930 correlation combinations over the 1901-1976 period for temperature means and precipitation sums, and 870 for scPDSI indices, for the winter (DJF) and summer (JJA) season (Figure S3, Supporting Information). The DJF and JJA temperatures (Figures S3a and S3b, Supporting Information) remained positively correlated over a longer distance and appear more homogeneous $\left(R^{2}=0.96-0.97\right)$ than precipitation for

228 the same two seasons $\left(R^{2}=0.62-0.66\right)$ (Figures S3c and S3d, Supporting Information). 229 Correlations between DJF temperatures are highly significant ( $\mathrm{p}<0.001)$ up to $2600 \mathrm{~km}$ and 
JJA temperatures up to $1500 \mathrm{~km}$. Precipitation sums for DJF and JJA exceed the $99.9 \%$

231 significance level up to the $600 \mathrm{~km}$ and $350 \mathrm{~km}$ range, respectively. The scPDSI correlations, 232 between grid points dispersed over $4000 \mathrm{~km}$, display similar patterns as found with 233 precipitation (Figures S3e and S3f, Supporting Information).

\subsection{Growth-climate responses}

236 The growth-climate response for the Med. region, as a whole, shows significant negative correlations to summer temperature (May to September: $r=-0.31, \mathrm{p}<0.01$ ) and maximum positive correlations to June/July precipitation with $r=0.4(\mathrm{p}<0.01)$ (Figure 5). Correlations with scPDSI were highest for July to September $(r=0.23 ; \mathrm{p}<0.05)$.

240 The climatic response of the Med. West and Med. East composite TRW chronologies differ 241 strongly. The Med. West shows a generally weaker climate response than Med. East on both spatial and temporal scales (Figures 6 and 7). Med. East correlates positively with scPDSI (from June with $r=0.28$ up to $r=0.38$ for October, $\mathrm{p}<0.01$ ), whereas scPDSI correlations with Med. West are negative (June-October: $r=-0.12$, insignificant). Moreover, the seasonality of the climate response to scPDSI differs between the regions: summer (JJA: $r=$ 0.35, $\mathrm{p}<0.01$ ) for Med. East versus spring (MAM: $r=-0.21, \mathrm{p}<0.05$ ) for Med. West. The distinct drought signal in the eastern TRW chronologies is supported by positive correlations with summer $(\mathrm{JJA})$ precipitation $(r=0.43, \mathrm{p}<0.01)$ and negative correlations with summer temperatures $(r=-0.34, \mathrm{p}<0.01)$. Although the growth response to JJA precipitation totals is significant over the entire 20th century, there is still a decrease in the obtained growth-climate 251 relationship that occurred during the mid-1950s (Figure 6b).

252 Correlations between precipitation and temperature, and the western chronologies, were rarely significant (Figures 5 and 6). JJA temperatures produced strong negative correlations for 254 Med. and Med. E in the eastern Mediterranean Basin, with extension towards Greenland, 
whereas Med. W shows positive correlations across northern Spain and the Pyrenees

256 stretching towards west - and central Europe (Figure 7a).

257 Subgroups Med. W1 (central Spain) and Med. W2 (Pyrenees) reveal statistically insignificant 258 growth-climate response patterns for precipitation and only Med. W2 shows a significantly 259 positive association with temperature in May $(r=0.28 ; \mathrm{p}<0.05)$. Both subgroups yield 260 significant negative correlations to scPDSI in the spring and summer season (April-July: $r=-$ $2610.22, \mathrm{p}<0.05)$. This can be explained by favored tree growth under warm spring and summer conditions, especially for Med. W2 (Figure S4, Supporting Information).

Italy forms a separate cluster based on the first PCA (Figure 3a), its correlation results correspond to those for the western Mediterranean. Most notable are the significant negative correlations with spring and summer scPDSI, reaching a maximum in April $(r=-0.24, \mathrm{p}<$ 0.05) (Figure S4, Supporting Information). Spatial field correlations for the JJA season, however, show significant $(\mathrm{p}<0.05)$ positive associations with JJA temperature across the broader Mediterranean Basin and Europe (Figure S5, Supporting Information).

Composite TRW chronologies Med. E1 (Turkey plus Cyprus) and Med. E2 (southern Balkans) show negative associations with summer temperatures of the previous as well as the current year, and positive associations with precipitation over the same time period (Figure S4, Supporting Information). The strongest correlations for Med. E1 were found with precipitation in May-August $(r=0.44, \mathrm{p}<0.01)$. Conditions limiting tree growth are thus

274 found during hot and dry summers (May to August), represented by positive but weak 275 correlations with scPDSI, that increase with decreasing latitude from $r=0.11(\mathrm{p}>0.1)$ for 276 Med. E2 to $r=0.29$ for Med. E1 ( $p<0.01$ ). Spatial correlations for the JJA season are strongly significant for both sub-groups in the eastern Mediterranean and extend towards to south-eastern tip of Greenland, a pattern more distinct for Med. E1 than for Med. E2 (Figure S5, Supporting Information). 
Overall, our results show that tree growth is controlled by a combination of temperature and 281 precipitation variations in summer, expressed as a dipole growth response between the western and eastern Mediterranean. These differences are also visible at the composite TRW chronology level and at different frequencies (Figure 4).

\section{Discussion}

\subsection{Temporal and spatial variability within the network}

We found that the first PC axis explains close to $20 \%$ of the variance across the whole Mediterranean TRW network and indicates a common growth pattern across the Mediterranean. At lower hierarchical orders, the PCA yielded a strict division between the eastern and the western Mediterranean, but the position of the central Mediterranean, represented by Italy, remains unclear. Our results show a time-stable discrepancy between West and East Mediterranean sites over the last 700 years (1330-2008) at different temporal resolutions (Figure 4), which is also manifested in the very low number of common extreme years. The majority of positive extreme years, common to both Med. W and Med. E, can be related to volcanic eruptions (i.e., 1450 \pm 10 Kuwae, 1580+30 Billy Mitchel, 1845 Hekla, 1883 Krakatau, 1914 Sakurajima; Zielinski, 1995, Oppenheimer, 2003) which cause cooler climate over Europe (Esper et al., 2013) and favorable growing conditions in the Mediterranean Basin.

Significant intra- and inter-species associations between TRW-chronologies are largely 300 restricted to a $500 \mathrm{~km}$ range (Figure S2, Supporting Information). Nevertheless, we found 301 potential connections over longer distances between a variety of pine species, e.g. $P$. heldreichii and P. nigra In general, the intra-species associations were stronger with some stretching as far as $1500 \mathrm{~km}$. Frank and Esper (2005) found a similar result for a multi-species

304 TRW network in the Alps, as have Kuniholm and Striker (1987) for the Aegean. In the 
western Mediterranean, Rolland (2002) found strong correlations between remote (> $500 \mathrm{~km})$ P. uncinata stands and Richter et al. (1991) between four pine species up to $450 \mathrm{~km}$ distance.

307 Mediterranean pine growth associations thus appear to mimic decreasing climatic association trends with increasing distance (Figure S3, Supporting Information). Inter-annual temperature variability shows strong homogeneity within a $2500 \mathrm{~km}$ radius (e.g., Jones et al., 1997;

310 Büntgen et al., 2010b), but precipitation and summer drought patterns are more regionalized 311 due to topography and continentality and show weaker connections beyond $500 \mathrm{~km}$. It is worth noting that our analyses were based on grid point data (CRU TS3.1) intended to overcome the absence of long instrumental station data for some regions. These data do not necessarily fully represent local site conditions, particularly for mountain environments, because often is the case that the meteorological stations used to produce any given grid-point interpolation are not always local to that grid-point.

\subsection{Climate sensitivity}

319 Our comparison of the east and the west pine sites shows a minor elevational bias (Figure 8d), 320 but elevation does not play a crucial role in the climate signal of the pine composite chronologies (Table S1 and Figure S4, Supporting Information). We found that pine growth at mid and high altitudes (1500 - $2250 \mathrm{~m}$ a.s.1.) has a drought or a mixed climate signal, whereas pines at the maximum elevation tree-line sites in the Pyrenees (2250- $2500 \mathrm{~m}$ a.s.1.) primarily respond to late spring - summer temperature (Table S1 and Figure S4, Supporting Information). It is important to note that we focused our analysis on strong climate signals in mid-to high elevation pines and thus have not considered the climate response of pine sites below $1500 \mathrm{~m}$ a.s.1. in our analyses.

Our Mediterranean TRW network is divided into biogeographically coherent sub-regions despite the potential lack of an evenly distributed network of sampling sites. This implies that environmental factors rather than species-specific influences dominate tree growth (Figure 8). 
For instance, Pinus nigra, present in the east and west Mediterranean, shows a contrasting

332 response to summer drought, which depresses tree growth in the western Mediterranean but 333 promotes it in the East (Figure 8f). In general, trees in the western Mediterranean share a 334 stronger common signal (explained common variance of 29.5\%), but the growth-climate 335 response is more moderate than for the eastern Mediterranean. The stronger common signal in 336 the western pine chronologies can be explained by the smaller geographical range covered by 337 those sites. The low climate sensitivity may be explained by ecological controls on growth: 338 cooler temperatures at high elevations enhance temperature limitations on tree growth (e.g., in 339 the Pyrenees) in addition to drought influences, leading to a mixed climatic response. At 340 lower elevations evaporative demand and precipitation is generally lower whereas in dry 341 regions drought predominantly constrains radial growth (e.g., in central Spain) (Figure S4, 342 Supporting Information).

343 The western pines thus react negatively to drought and their growth-climate response pattern 344 resembles that identified by Richter et al. (1991). These results are in accordance with earlier 345 studies for the Pyrenees, where positive but weak and unstable correlations to summer 346 temperatures were found (Tardif et al., 2003; Büntgen et al., 2010a). A higher diversity of 347 growth-climate relations was found for central Spain. Gutiérrez et al. (1989) stated that 348 drought at the beginning of the growing season (March) and in summer (June) affect $P$. 349 sylvestris growth in southern Catalonia. P. uncinata from the central plains of Spain (Genova, 350 1986) and P. nigra from the eastern part of the Iberian Peninsula (Martín-Benito et al., 2010) 351 show a summer drought signal, that is further enhanced towards southern Spain (Richter et 352 al., 1991).

353 Summer drought is also the strongest climate signal in TRW records of the eastern 354 Mediterranean region. The strength of the drought signal generally increases with decreasing 355 latitude and increasing eastern longitude from the Balkans (Med. E2) to Turkey and Cyprus 356 (Med. E1). A rather weak and unstable climate signal was observed in some regional studies, 
especially for $P$. heldreichii at high elevation sites in the Balkan region (Panayotov et al., 2010; Seim et al., 2012). Further south, where the Mediterranean climate is more pronounced (Figure 1b), a strong positive influence of summer precipitation has resulted in numerous drought reconstructions derived from a variety of pine species (e.g., D'Arrigo and Cullen, 2001; Touchan et al., 2003; Akkemik and Aras, 2005), and confirms the higher potential for TRW-based drought reconstructions using pines in the eastern rather than the western Mediterranean region. In more detail, Touchan et al. (2014) identified even sub-regional patterns and the high potential for seasonal climate reconstructions in a multi-species network study for the eastern Mediterranean.

A potential reason for the seasonal shift in climate response is the development of different strategies to compensate dehydration. Pines in Med. West need to adapt to drought conditions at the beginning of the growing season (spring/ early summer) while pines in Med. East are generally more stressed during summer (Figure 5). Evidence for structural adaption to drought is provided in a study of $P$. sylvestris along a north-south transect across Europe by Palmroth et al. (1999). Especially at mountain sites where shallow soils have a limited water storage capacity, water deficit during hot summers causes i) changes in the cell structure by increasing the cell lumen diameter to improve water conduction (Eilmann et al., 2011), and ii) a general reduction in cell number leading to narrower tree rings especially at high altitudes (e.g., Gruber et al., 2010).

\subsection{Climate dynamic effects on mountain pine tree growth}

The identified groupings of our pine TRW network can only be explained by differences in synoptic climate pattern across the Mediterranean. Mediterranean pine growth is mainly influenced by synoptic-scale patterns of summer drought, which is consistent with the first canonical mode of summer temperature data (1950-1999) across the Mediterranean region found by Xoplaki et al. (2003). During summer, insolation is increased, due to predominantly 
clear skies, and a stable warm high pressure in the Mediterranean Basin (Xoplaki et al., 2003).

Additionally, the second canonical mode found by Xoplaki et al. (2003) highlights differences in climate between the western and the eastern Mediterranean, which supports the poor agreement between our composite chronologies Med. East and Med. West (Figure 4 and 7) . One reason for the east-west difference in summer climate lies in the influence of the East Atlantic jet stream expressed by westerly winds, which have a stronger cooling effect in the West compared to the East (Dünkeloh and Jacobeit, 2003; Xoplaki et al., 2003). Moreover, both empirical and ensemble modeling evidence, based on an array of climate variables, 392 identified variability in the western Mediterranean that co-varies with the West African 393 Monsoon (Fontaine et al., 2010). Finally, the summer North Atlantic Oscillation (sNAO) is a 394 strong driver of temperature variability in the eastern Mediterranean, but not in the West 395 (Folland et al., 2009; Trouet et al., 2012).

In addition to this, the oceanic-continental gradient ranging from Spain to Turkey is 397 interrupted by the Mediterranean Sea, a pool of permanent heat and vapor exchange, and by 398 regional winds such as the Westerly, Mistral or Sirocco. This leads to a complex 399 Mediterranean climate with multiple drivers, especially in summer (Pauling et al., 2006). 400 Further reasons for spatial climate differences can be found in the Hadley circulation that 401 triggers the overturning of air masses in the troposphere and shows a descending motion in 402 the subtropics (Hadley, 1735). This circulation is strongly related to west-east jet streams 403 (tropopause-level westerlies) and varies seasonally (Dima and Wallace, 2003). In summer, the 404 Hadley cell moves northwards, towards eastern North Africa, and the impact of the Asian monsoon in the mid-troposphere becomes stronger, particularly in the eastern Mediterranean

406 (Ziv et al., 2004). According to Ziv et al. (2004), the Asian monsoon enhances the subsidence 407 of air masses over the east Mediterranean and enforces the Etesian winds equalizing low-level 408 pressure differences between the two regions. The prevailing low-pressure system across the 
eastern Mediterranean is linked with high pressure areas in North-West, East but also in

410 Central Europe (Arseni-Papadimitriou et al., 1988; Luterbacher et al., 2012). These linkages

411 are confirmed by Ziv et al. (2004) for the sNAO, the leading eigenvector for July/August

412 mean sea level pressure over the North Atlantic (Hurrell and Folland, 2002). Proxy evidence

413 (1768-2008) for a teleconnection pattern between the Balkans and north-western Europe was

414 found by Trouet et al. (2012), who developed a temperature reconstruction for Bulgaria

415 (Balkan, eastern Mediterranean) using tree-ring maximum latewood density.

416

\section{Conclusion}

A Mediterranean pine network of 2186 individual TRW measurement series from 54 mid- to high-elevation sites was compiled and analyzed. The first PCA contains almost $20 \%$ of the total network variance, whereas higher order components demonstrate that tree-ring variability differs significantly between the West and East Mediterranean regions. The eastwest dipole in pine growth is supported by the correlation decay of $\sim 500 \mathrm{~km}$ representing decreasing drought association trends with increasing distance. The climate-growth response of pines in the western part of the network is more moderate favoring warm temperatures in spring and early summer, especially in the Pyrenees, likely caused by site characteristics. By contrast the growth rates of pines in the East are higher under cold-wet conditions. Specific atmospheric circulation patterns and corresponding differences in climatic drivers likely cause the distinct, zonal, inter-annual to decadal-scale growth response patterns. Our results point to a larger potential for TRW-based drought reconstructions in the eastern Mediterranean region as opposed to the West, but demonstrate in general the challenges for climate reconstructions based on mid- to high elevation Mediterranean pines.

\section{Acknowledgments}


434 We thank the ITRDB contributors, as well as L. Todaro and P. I. Kuniholm for their data. A. 435 Bast, B. Ullrich G. Gea-Izquierdo and two anonymous reviewers provided useful comments 436 and suggestions. This study was supported by the European Science Foundation (2909 437 'Medclivar'), Swedish International Development Cooperation Agency SIDA (project SWE438 2009-245), the European Union (GOCE 017008-2 'MILLENNIUM'), and the Swiss National 439 Science Foundation (NCCR-Climate).

440 


\section{References}

443 Akkemik Ü, Aras A. 2005. Reconstruction (1689-1994 AD) of April-August precipitation in 444 the southern part of central Turkey. International Journal of Climatology 25: 537-548.

Arseni-Papadimitriou A, Maheras P, Giles BD. 1988. Contribution to the study of the strong north winds on Aegean Sea, in the warm season. Rivista di Meteorologia Aeronautica 48(34): 131-138.

Barbéro M, Loisel R, Quézel P, Richardson, DM, Romane F. 1998. Pines of the Mediterranean Basin. In Ecology and Biogeography of Pinus, Richardson DM (ed). Cambridge University Press: Cambridge; 153 -170.

Büntgen U, Frank D, Trouet V, Esper J. 2010a. Diverse climate sensitivity of Mediterranean tree-ring width and density. Trees 24: 261-273.

Büntgen U, Franke J, Frank D, Wilson R, González-Rouco F, Esper J. 2010b. Assessing the spatial signature of European climate reconstructions. Climate Research 41: 125-130.

Cook ER, Peters K. 1997. Calculating unbiased tree-ring indices for the study of climatic and 461 environmental change. The Holocene 7: 361-370. 
D’Arrigo RD, CullenHM. 2001. A 350-year (AD 1628-1980) reconstruction of Turkish precipitation. Dendrochronologia 19: 167-177.

469

470 de Luis M, Čufar K, Di Filippo A, Novak K, Papadopoulos A, Piovesan G, Rathgeber CBK, 471 Raventós J, Angel Saz M, Smith KT. 2013. Plasticity in Dendroclimatic Response across the 472 Distribution Range of Aleppo Pine (Pinus halepensis). PLOS ONE 8(12), DOI: 473 10.1371/journal.pone.0083550.

474

Dima IM, Wallace JM. 2003. On the seasonality of the Hadley cell. Journal of the Atmospheric Sciences 60: 1522-1527.

477

Dünkeloh A, Jacobeit J. 2003. Circulation dynamics of Mediterranean precipitation variability 1948-98. International Journal of Climatology 23(15): 1843-1866.

480

Eilmann B, Zweifel R, Buchmann N, Graf Pannatier E, Rigling A. 2011. Drought alters 482 timing, quantity, and quality of wood formation in Scots pine. Journal of Experimental 483 Botany 62(8): 2763-2771.

484

Esper J, Schneider L, Krusic PJ, Luterbacher J, Büntgen U, Timonen M, Sirocko F, Zorita E. 2013. European summer temperature response to annually dated volcanic eruptions over the past nine centuries. Bulletin of Volcanology 75, DOI: 10.1007/s00445-013-0736-z. 
493 Gervois S, Sijikumar S, Ruti P, Janicot S. 2010. Impacts of warm and cold situations in the

494 Mediterranean basins on the West African monsoon: observed connection patterns (1979495 2006) and climate simulations. Climate Dynamics 35: 95-114.

Frank DC, Esper J. 2005. Characterization and climate response patterns of a high-elevation, multi-species tree-ring network in the European Alps. Dendrochronologia 22: 107-121.

Gao X, Giorgi F. 2008. Increased aridity in the Mediterranean region under greenhouse gas Planetary Change 62: 195-209.

Genova R. 1986. Dendroclimatology of mountain pine (Pinus uncinata Ram.) in the central plain of Spain. Tree-Ring Bulletin 46: 3-12.

Grissino-Mayer HD, Fritts HC. 1997. The International Tree-Ring Data Bank: An enhanced global database serving the global scientific community. The Holocene 7: 235-238.

Gruber A, Strobl S, Veit B, Oberhuber W. 2010. Impact of drought on the temporal dynamics of wood formation in Pinus sylvestris. Tree Physiology 30(4): 490-501.

Gutiérrez E. 1989. Dendroclimatological study of Pinus sylvestris L. in southern Catalonia (Spain). Tree-Ring Bulletin 49: 1-9. 
519 Holmes RL. 1983. Computer assisted quality control in tree-ring dating and measurement. $520 \quad$ Tree-Ring Bulletin 43: 69-78.

Hughes MK, Kuniholm PI, Eischeid JK, Garfin G, Griggs CB, Latini C. 2001. Aegean treering signature years explained. Tree-Ring Research 57(1): 67-73.

Hurrell JW, Folland CK. 2002. The relationship between tropical Atlantic rainfall and the summer circulation over the North Atlantic. CLIVAR Exchanges 25: 52-54.

IPCC, 2013. Climate Change 2013: The Physical Science Basis. Contribution of Working

Group I to the Fifth Assessment Report of the Intergovernmental Panel on Climate Change Cambridge, United Kingdom and New York, NY, USA.

Kuniholm PI, Striker CL. 1987. Dendrochronological investigations in the Aegean and neighboring regions, 1983-1986. Journal of Field Archaeology 14(4): 385-398.

Ludwig JA, Reynolds JF. 1988. Statistical ecology, John Wiley and Sons, New York.

Luterbacher J, and 33 co-authors. 2012. A review of 2000 years of paleoclimatic evidence in 538 the Mediterranean. In The Climate of the Mediterranean region: From the Past to the Future, 539 Lionello P (ed). Elsevier: Amsterdam; 87-185.

541 Martín-Benito D, del Río M, Cañellas I. 2010. Black pine (Pinus nigra Arn.) growth 542 divergence along a latitudinal gradient in Western Mediterranean mountains. Annals of Forest 543 Science 67(4). DOI: 10.1051/forest/2009121. 
545 Mitchell TD, Jones PD. 2005. An improved method of constructing a database of monthly

546 climate observations and associated high-resolution grids. International Journal of

547 Climatology 25: 693-712.

549 Oppenheimer C. 2003. Ice core and palaeoclimatic evidence for the timing and nature of the 550 great mid-13th century volcanic eruptions. International Journal of Climatology 23: 417-426.

PAGES 2k Consortium. 2013. Continental-scale temperature variability during the past two millennia. Nature Geoscience 6: 339-346.

Palmroth S, Berninger F, Nikinmaa E, Lloyd J, Pulkkinen P, Hari P. 1999. Structural adaptation rather than water conservation was observed in Scots pine over a range of wet and dry climates. Oecologia 121: 302-309.

Panayotov M, Bebi P, Trouet V, Yurukov S. 2010. Climate signals in Pinus peuce and Pinus heldreichii tree-ring chronologies from the Pirin mountains in Bulgaria. Trees 24: 479-490.

562 Pauling A, Luterbacher J, Casty C, Wanner H. 2006. Five hundred years of gridded high563 resolution precipitation reconstructions over Europe and the connection to large-scale 564 circulation. Climate Dynamics 26: 387-405.

566 Peters K, Jacoby GC, Cook ER. 1981. Principal components analysis of tree-ring sites. Tree- 
Richter K, Eckstein D, Holmes RL. 1991. The dendrochronological signal of pine trees (Pinus spp.) in Spain. Tree-Ring Bulletin 51: 1-13.

Rolland C. 2002. Decreasing teleconnections with inter-site distance in monthly climatic data and tree-ring width networks in a mountainous Alpine area. Theoretical and Applied

574 Climatology 71: 63-75.

Seim A, Büntgen U, Fonti P, Haska H, Herzig F, Tegel W, Trouet V, Treydte K. 2012. 51: $217-228$.

Sousa PM, Trigo RM, Aizpurua P, Nieto R, Gimeno L, Garcia-Herrera R. 2011: Trends and extremes of drought indices throughout the 20th century in the Mediterranean. Natural Hazards and Earth System Sciences 11: 33-51.

Tardif J, Camarero JJ, Ribas M, Gutiérrez E. 2003. Spatiotemporal variability in tree growth in the Central Pyrenees: climatic and site influences. Ecological Monographs 73(2): 241-257.

Touchan R, Garfin G, Meko DM, Funkhouser G, Erkan N, Hughes MK, Wallin BS. 2003.

Preliminary reconstructions of spring precipitation in Southwestern Turkey from tree-ring width. International Journal of Climatology 23: 157-171.

Touchan R, Anchukaitis KJ, Shishov VV, Sivrikaya F, Attieh J, Ketmen M, Stephan J,

592 Mitsopoulos I, Christou A, Meko DM. 2014. Spatial patterns of eastern Mediterranean 593 climate influence on tree growth. The Holocene. DOI: 10.1177/0959683613518594. 
595 Trouet V, Panayotov MP, Ivanova A, Frank DC. 2012. A pan-European summer 596 teleconnection mode revealed by a new temperature reconstruction from the northeastern 597 Mediterranean (1768-2008). The Holocene. DOI: 10.1177/0959683611434225.

598

599 Trouet V, van Oldenborgh GJ. 2013. KNMI Climate Explorer: a web-based research tool for 600 high-resolution paleoclimatology. Tree-Ring Research 69(1): 3-13.

601

602 van der Schrier G, Briffa KR, Jones PD, Osborn TJ. 2006. Summer moisture variability 603 across Europe. International Journal of Climatology 19: 2818-2834.

604

605 van Oldenborgh GJ, Burgers G 2005. Searching for decadal variations in ENSO

606 precipitation teleconnections. Geophysical Research Letters 32. DOI:

$607 \quad 10.1029 / 2005$ GL023110.

608

609 Wigley TML, Briffa KR, Jones PD. 1984. On the average of correlated time series, with 610 applications in dendroclimatology and hydrometeorology. Journal of Climate and Applied 611 Meteorology 23: 201-213.

612

613 Xoplaki E, Gonzalez-Rouco JF, Luterbacher J, Wanner H. 2003. Mediterranean summer air 614 temperature variability and its connection to the large-scale atmospheric circulation and SSTs. 615 Climate Dynamics 20: 723-739.

616

617 Ziv B, Saaroni H, Alpert P. 2004. The factors governing the summer regime of the eastern 618 Mediterranean. International Journal of Climatology 24: 1859-1871.

620 Zielinski GA. 1995. Stratospheric loading and optical depth estimates of explosive volcanism 
621 over the last 2100 years derived from the Greenland Ice Sheet Project 2 ice core. Journal of 622 Geophysical Research 100 (D10): 20,937-20,955.

623 


\section{Tables}

625

626 Table 1. Characteristics of the newly developed composite TRW chronologies with

627 combinations including the number of series per chronology, the start year, the robust period

628 (EPS > 0.85) until the end year, the total length in years, the inter-series correlation (Rbar),

629 the mean sensitivity and mean segment length (MSL).

\begin{tabular}{|lcccccccc|}
\hline $\begin{array}{l}\text { Comp. TRW- } \\
\text { chronology }\end{array}$ & $\begin{array}{c}\text { Number of } \\
\text { series }\end{array}$ & $\begin{array}{c}\text { Start } \\
\text { year }\end{array}$ & $\begin{array}{c}\text { EPS } \\
\mathbf{> 0 . 8 5}\end{array}$ & $\begin{array}{c}\text { End } \\
\text { year }\end{array}$ & Length & $\begin{array}{c}\text { Rbar } \\
\text { (raw) }\end{array}$ & $\begin{array}{c}\text { Mean } \\
\text { Sensivity }\end{array}$ & MSL \\
\hline Mediterranean & 2186 & 617 & 1345 & 2008 & 1392 & 0.28 & 0.22 & 241 \\
West & 1271 & 924 & 1330 & 2008 & 1085 & 0.34 & 0.22 & 217 \\
West without Italy & 1167 & 924 & 1305 & 2008 & 1085 & 0.37 & 0.22 & 210 \\
East & 915 & 617 & 1295 & 2008 & 1392 & 0.39 & 0.22 & 276 \\
Central Spain & 474 & 1485 & 1590 & 2008 & 524 & 0.41 & 0.24 & 230 \\
Pyrenees & 693 & 924 & 1330 & 2007 & 1084 & 0.48 & 0.19 & 196 \\
Italy & 104 & 1441 & 1525 & 2003 & 563 & 0.57 & 0.22 & 291 \\
Pyrenees plus Italy & 797 & 924 & 1330 & 2007 & 1084 & 0.42 & 0.20 & 208 \\
Balkan & 493 & 617 & 1295 & 2008 & 1392 & 0.48 & 0.21 & 312 \\
Turkey plus Cyprus & 422 & 1379 & 1555 & 2004 & 626 & 0.45 & 0.24 & 234 \\
\hline
\end{tabular}

631 
633
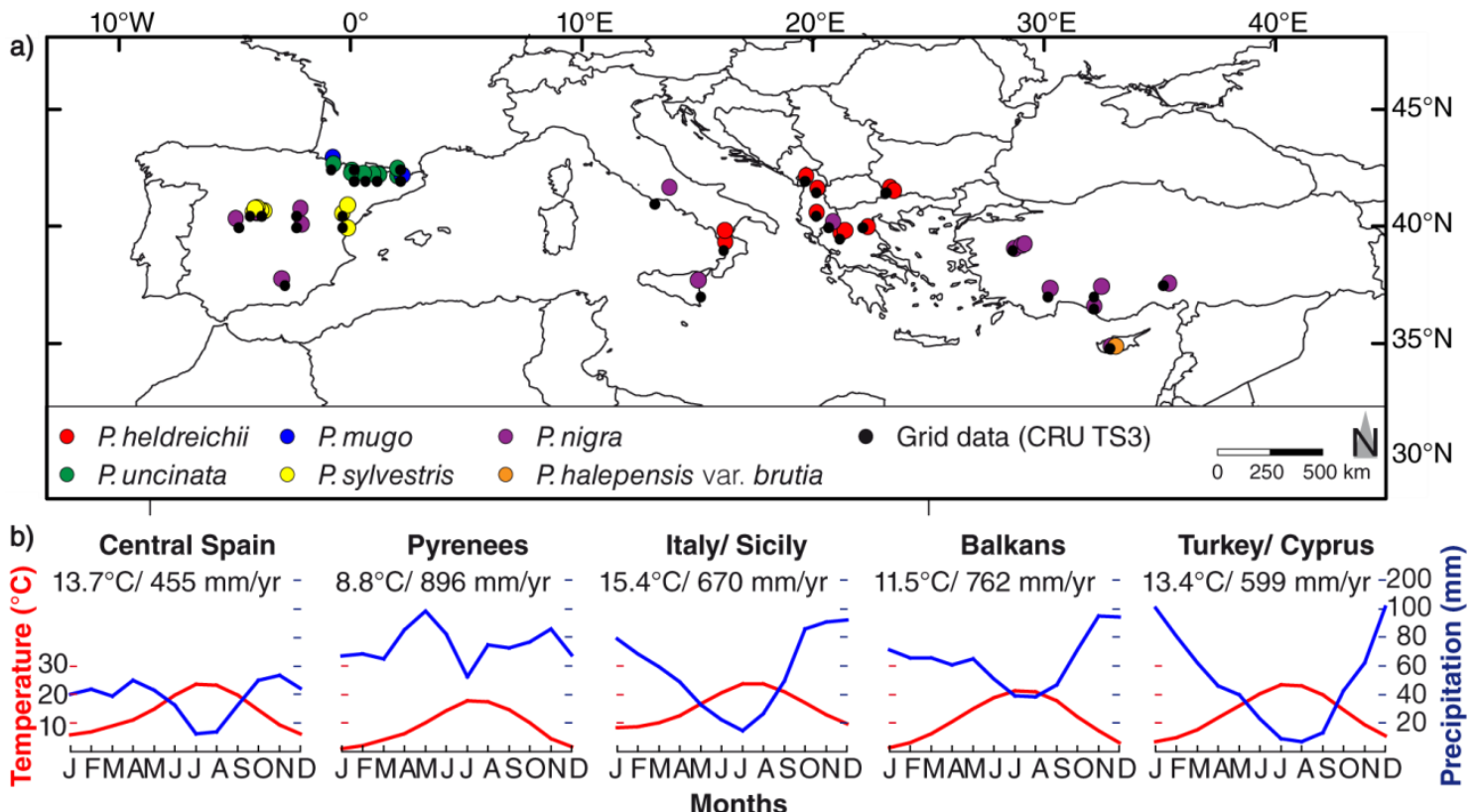

635 Figure 1. (a) Mediterranean TRW network of 54 pine sites and their closest grid-points (CRU

636 TS3.1) (b) Seasonal temperature and precipitation (red and blue lines) variability averaged

637 over the 1961-1990 period and obtained from the CRU TS3.1 data corresponding to the five 638 main TRW network regions. 


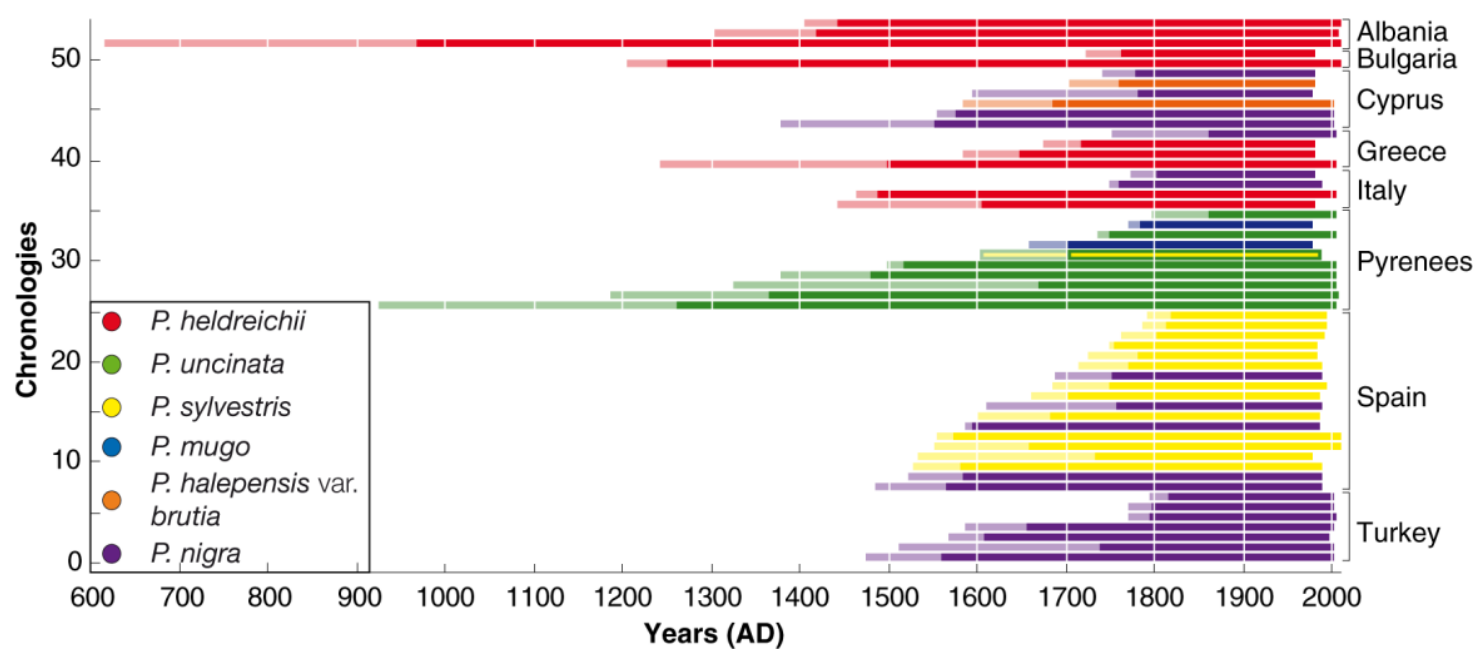

640 Figure 2. Replication of the TRW network in alphabetical country order and record lengths.

641 Each bar represents one individual chronology and colors represent different pine species.

642 Colors refer to chronologies' length after truncation $<5$ series, whereas shadings denote their 643 full lengths. 


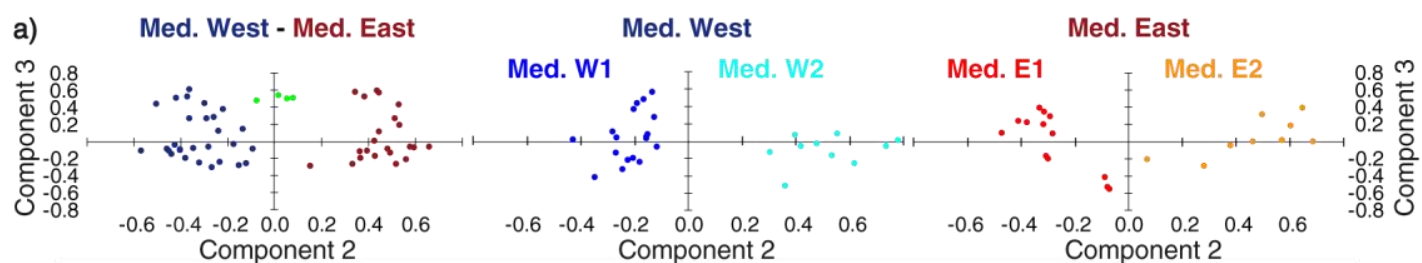

b)

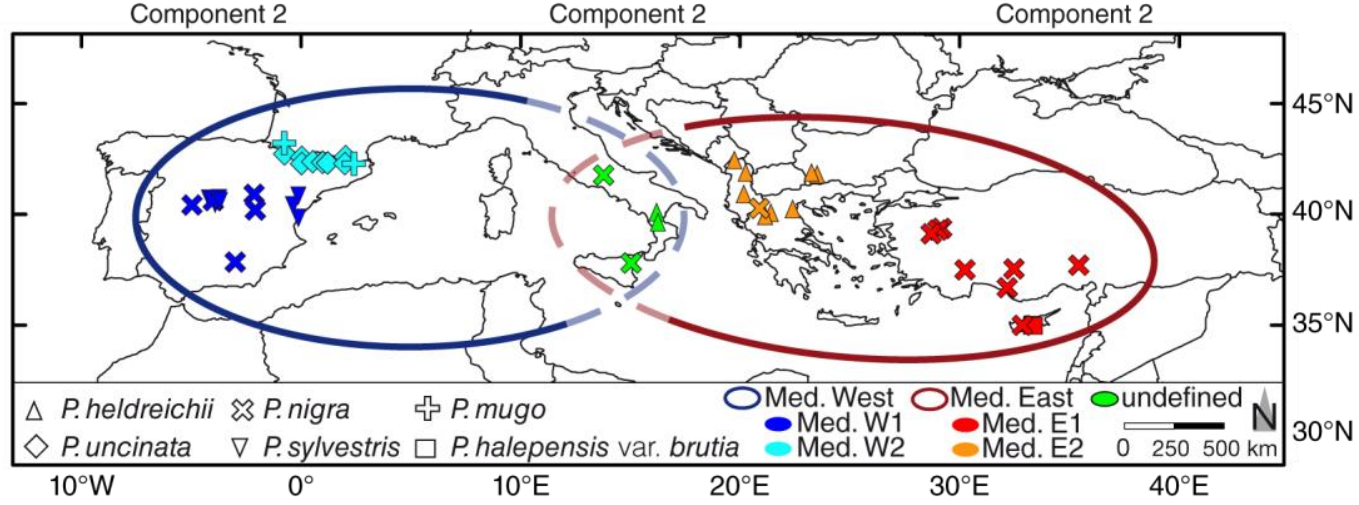

645 Figure 3. (a) Scatter plots of the PCA of all sites (power transformed 150-year spline 646 detrended TRW-chronologies) indicating the main principal components (PCs) Med. West 647 and Med. East and their subgroups (Med. W 1, Med. W2and Med. E1, Med. E2) for the 648 common period 1862-1976. (b) Spatial distribution of the various PCs (main PCs as ellipse, 649 subgroups in graduated colors) considering the tree species (symbols). 


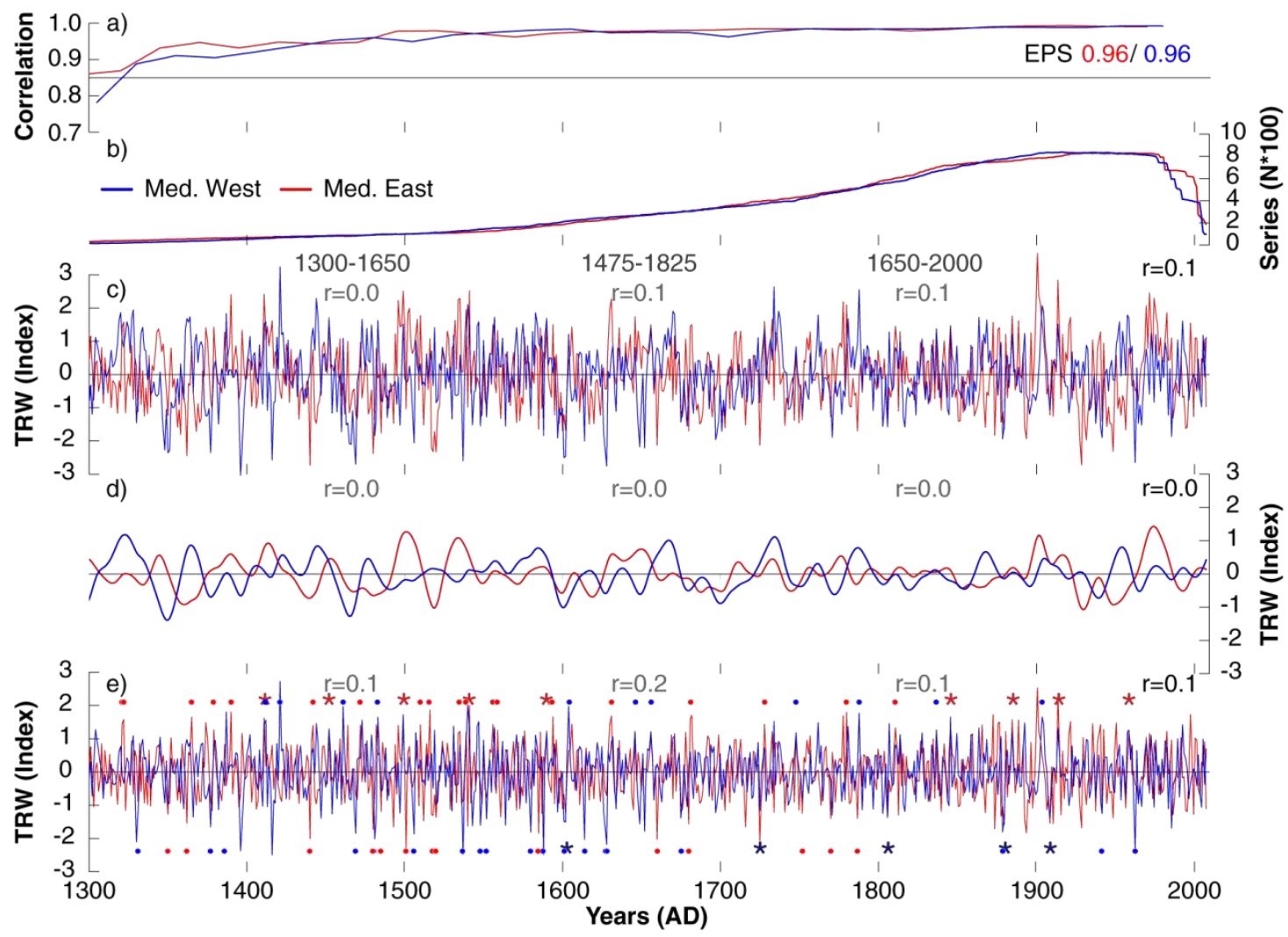

652 Figure 4. (a) Expressed population signal (EPS) and (b) replication for the (c) PT 150yr SPL 653 detrended and the 20-year (d) low-pass and (e) high-pass filtered composite chronologies 654 West (blue line) and East (red line) with individual (West: blue points; East: red points) and 655 common (asterisks) extreme years. Correlations between West and East were obtained for 656 338/339-year time windows in grey, and in black for the robust 1330-2008 period. 
658 Figure 5. Growth-climate response pattern between PT 150yr SPL detrended Med., Med.

659 West and Med. East composite chronologies and averaged gridded temperature, precipitation 660 and drought data (CRU TS3.1) calculated over the 1901-2002 periods using the 18 month 661 window. Raw Rbar values are shown for each PC subset over their full length and red 662 (dashed) lines indicate the (95\%) 99\% significance level. 


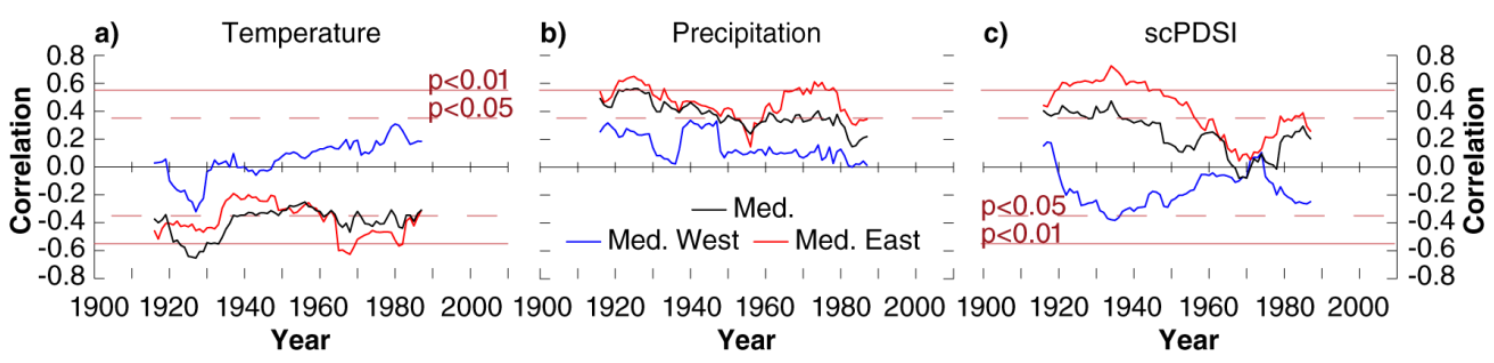

665 Figure 6. 31-year running correlation of JJA (a) temperature, (b) precipitation and (c) scPDSI

666 gidded data (CRU TS3.1) against composite TRW-chronology Med. (black), Med. West 667 (blue) and Med. East (red) over the 1901-2002 period. Red (dashed) lines indicate the (95\%) $66899 \%$ significance level. 

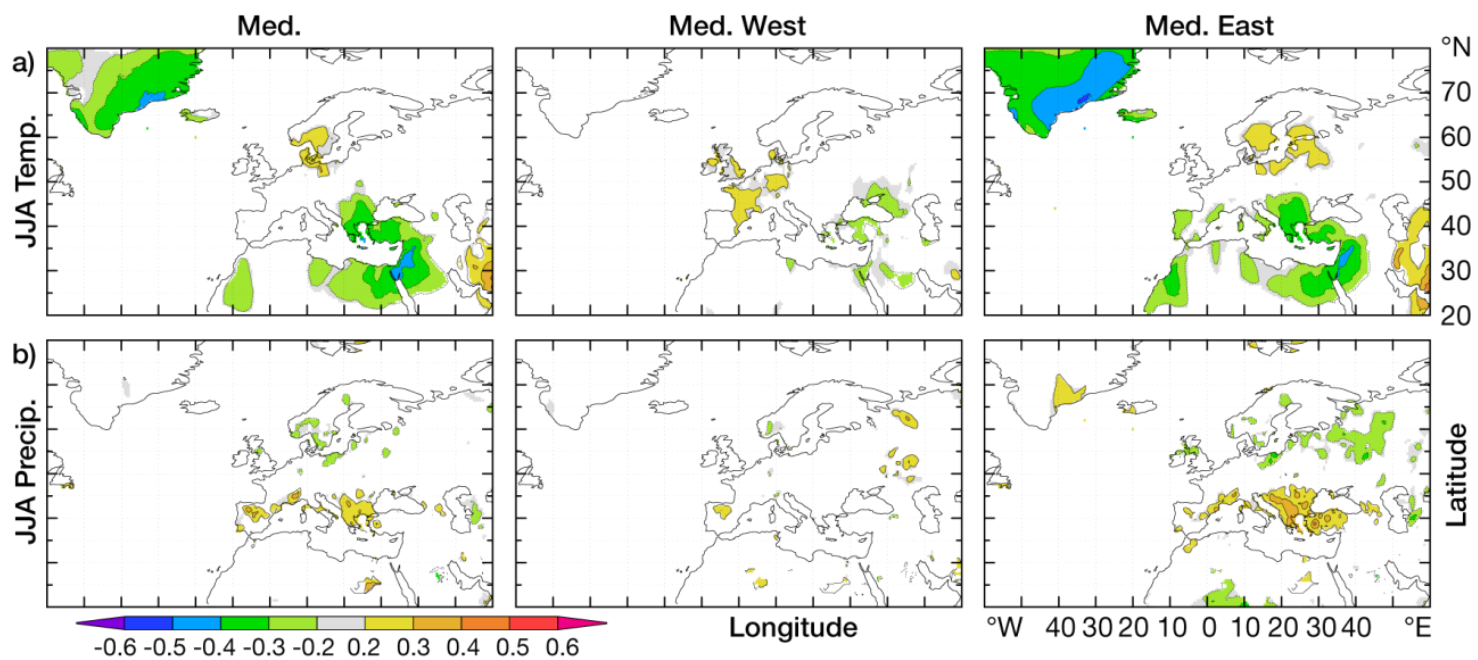

670 Figure 7. Spatial field correlations for composite TRW chronologies Med. (left), Med. W

671 (center), and Med. E. (right) against JJA (a) temperature (CRU TS3.1) and (b) precipitation 672 (CRU TS3.1) for the 1901-2002 periods.

673 

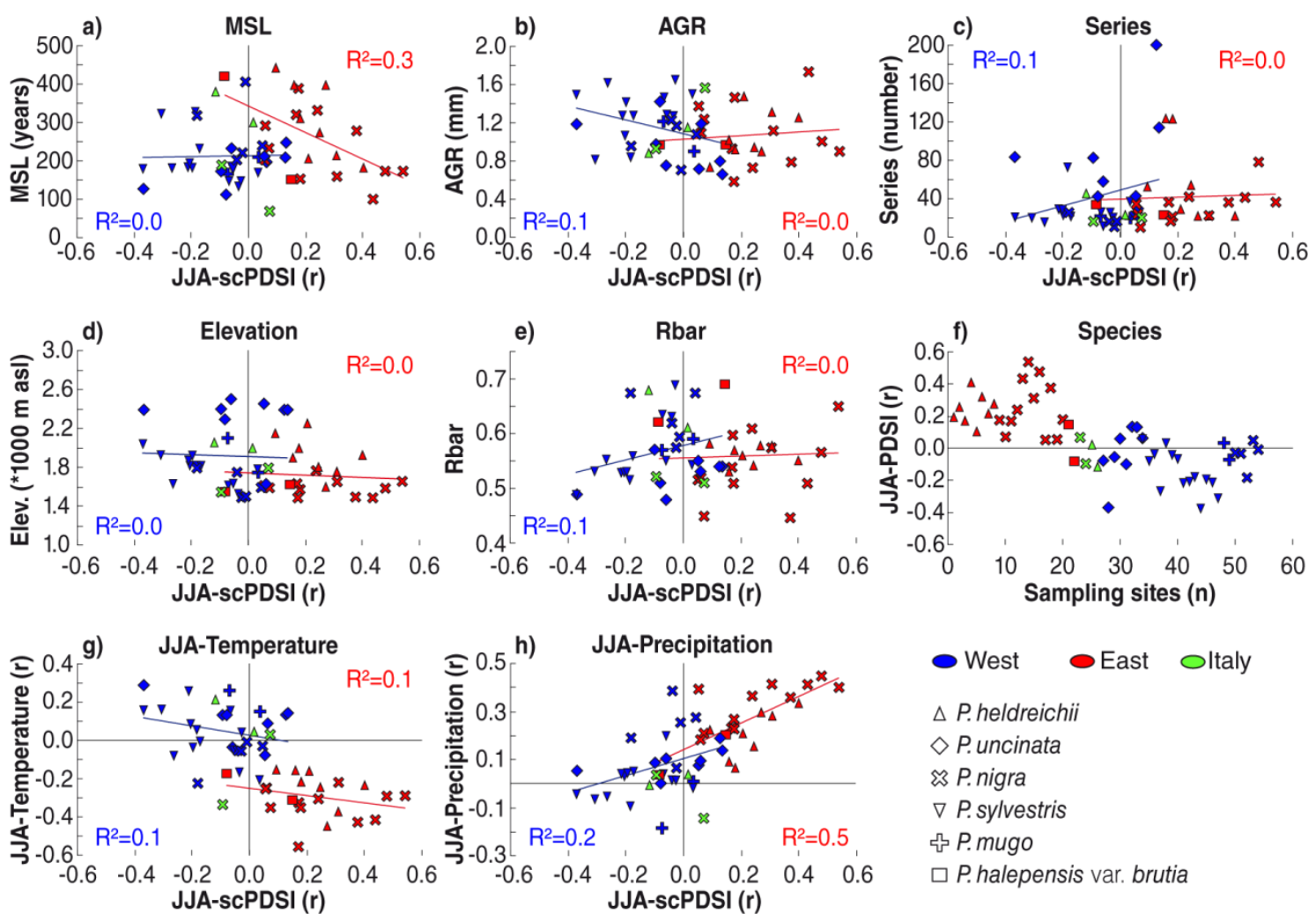

Figure 8. JJA-scPDSI grid point correlations of each site computed against its respective (a)

676 mean segment length (MSL), (b) average growth rate (AGR), (c) number of series, (d)

677 elevation, (e) inter-series correlation, (f) species, (g) JJA-temperature means and (h) JJA-

678 precipitation sums. $\mathrm{R}^{2}$ describes the trend of a linear regression model. Please note changes in

679 scales and inverse axes in (f). 


\section{Supporting information}

681 Table S1. Site locations used in this study.

\begin{tabular}{|c|c|c|c|c|c|c|c|c|c|c|c|c|c|c|}
\hline Country & Site name & Spec. & Lat. $(\mathrm{N})$ & Long. (E) & Elev. (m asl) & Period & Length & Series & MSL & AGR & Rbar & Contributor & JJA Temp & JJA Precip \\
\hline Albania & C. Partisan & PIHE & 40.70 & 20.13 & $1900-2100$ & $1405-2008$ & 604 & 124 & 310 & 0.92 & 0.57 & A. Seim & -0.21 & 0.06 \\
\hline Albania & Thethi & PIHE & 42.42 & 19.77 & $1700-1900$ & $1303-2007$ & 705 & 54 & 275 & 0.94 & 0.54 & A. Seim & -0.25 & 0.16 \\
\hline Albania & Lura & PIHE & 41.80 & 20.23 & $1800-2000$ & $617-2008$ & 1392 & 124 & 397 & 1.02 & 0.53 & A. Seim & -0.16 & 0.09 \\
\hline Bulgaria & Vihren Nat. Park & $\mathrm{PIHE}$ & 41.77 & 23.38 & 1920 & 1721-1981 & 261 & 22 & 183 & 1.26 & 0.55 & F. Schweingruber & -0.24 & 0.33 \\
\hline Bulgaria & Vihren Nat. Park & PIHE & 41.75 & 23.43 & 2150 & $1206-2008$ & 759 & 53 & 441 & 0.73 & 0.58 & M. Panayotov & -0.15 & 0.22 \\
\hline Cyprus & Plano platres (humid) & PINI & 34.90 & 32.90 & 1600 & $1742-1981$ & 240 & 22 & 153 & 1.47 & 0.51 & F. Schweingruber & -0.35 & 0.27 \\
\hline Cyprus & Plano platres (dry) & PIBR & 34.90 & 32.90 & 1620 & 17031981 & 279 & 22 & 151 & 0.97 & 0.69 & F. Schweingruber & -0.31 & 0.20 \\
\hline Cyprus & Troodos Mountains & PINI & 34.92 & 32.88 & 1600 & $1594-1978$ & 385 & 11 & 236 & 1.25 & 0.45 & P.I. Kuniholm, C. Griggs & -0.35 & 0.21 \\
\hline Cyprus & Armiantos & PIBR & 34.92 & 32.90 & 1550 & $1584-2002$ & 419 & 33 & 419 & 0.96 & 0.62 & R. Touchan, M. Hughes & -0.17 & 0.03 \\
\hline Cyprus & Armiantos & PINI & 34.92 & 32.90 & 1640 & $1554-2002$ & 449 & 38 & 321 & 0.93 & 0.54 & R. Touchan, M. Hughes & -0.55 & 0.24 \\
\hline Cyprus & Chionistra & PINI & 34.93 & 32.87 & 1770 & $1379-2002$ & 624 & 44 & 332 & 0.74 & 0.61 & R. Touchan, M. Hughes & -0.30 & 0.37 \\
\hline Greece & $\begin{array}{l}\text { Scotida Forest, } \\
\text { Kastoria }\end{array}$ & PINI & 40.30 & 20.90 & 1500 & $1751-2003$ & 253 & 42 & 100 & 1.74 & 0.51 & P.I. Kuniholm, N. Riches & -0.41 & 0.42 \\
\hline Greece & $\begin{array}{l}\text { Katara Pass, } \\
\text { Metsovon }\end{array}$ & PILE & 39.80 & 21.22 & 1750 & 1673-1981 & 309 & 22 & 215 & 1.31 & 0.58 & F. Schweingruber & -0.37 & 0.29 \\
\hline Greece & Olympos Oros & PILE & 40.08 & 22.42 & 2250 & 1583-1981 & 399 & 30 & 207 & 1.47 & 0.56 & F. Schweingruber & -0.16 & 0.21 \\
\hline Greece & Grevena & PILE & 39.92 & 21.17 & 1600 & $1243-2004$ & 762 & 22 & 398 & 0.90 & 0.58 & P.I. Kuniholm & -0.45 & 0.30 \\
\hline Italy & Aetna, Linguaglossa & PINI & 37.78 & 15.05 & 1800 & $1773-1980$ & 208 & 20 & 65 & 1.56 & 0.51 & F. Schweingruber & 0.03 & -0.14 \\
\hline |italy & $\begin{array}{l}\text { Camosciara e Monte } \\
\text { Amaro }\end{array}$ & PINI & 41.77 & 13.82 & 1550 & $1750-1987$ & 238 & 16 & 184 & 0.93 & 0.52 & F. Biondi & -0.34 & 0.04 \\
\hline |italy & $\begin{array}{l}\text { Mt. Pollino, Serra di } \\
\text { Crispo }\end{array}$ & PILE & 39.43 & 16.23 & 2000 & 1441-1980 & 540 & 22 & 301 & 1.15 & 0.61 & F. Schweingruber & 0.04 & 0.04 \\
\hline |italy & $\begin{array}{l}\text { Mt. Pollino, Serra di } \\
\text { Crispo }\end{array}$ & PILE & 39.93 & 16.20 & 2054 & $1464-2003$ & 540 & 46 & 378 & 0.89 & 0.68 & L. Todaro & 0.21 & -0.01 \\
\hline Pyrenees & $\begin{array}{l}\text { France, Pic de sept } \\
\text { Hommes }\end{array}$ & PIUN & 42.29 & 2.25 & 2300 & $1798-2005$ & 208 & 42 & 113 & 1.43 & 0.51 & U. Büntgen & 0.14 & 0.00 \\
\hline Pyrenees & $\begin{array}{l}\text { France, Roc de } \\
\text { Perches Blancas }\end{array}$ & PIMG & 42.60 & 2.05 & 2100 & 1769-1977 & 209 & 22 & 169 & 1.23 & 0.57 & F. Schweingruber & 0.27 & -0.18 \\
\hline Pyrenees & France, Eyne & PIUN & 42.28 & 2.07 & 2400 & $1736-2004$ & 269 & 83 & 126 & 1.18 & 0.49 & U. Büntgen & 0.29 & 0.05 \\
\hline Pyrenees & France, Pic d'Anie & PIMG & 42.97 & -0.73 & 1750 & 1659-1977 & 319 & 20 & 212 & 0.91 & 0.59 & F. Schweingruber & 0.15 & 0.01 \\
\hline Pyrenees & $\begin{array}{l}\text { Spain, Hecho Puerto } \\
\text { de Acher }\end{array}$ & $\begin{array}{l}\text { PISYI } \\
\text { PIUN }\end{array}$ & 42.80 & -0.70 & 1625 & $1605-1985$ & 381 & 30 & 196 & 1.19 & 0.53 & K. Richter & 0.09 & 0.10 \\
\hline Pyrenees & Spain, Sobrestivo & PIUN & 42.42 & 0.06 & 2500 & $1499-2005$ & 507 & 58 & 233 & 0.75 & 0.48 & U. Büntgen & -0.04 & 0.10 \\
\hline Pyrenees & Spain, Port de Cabus & PIUN & 42.32 & 1.25 & 2450 & $1377-2005$ & 629 & 42 & 213 & 0.72 & 0.55 & U. Büntgen & -0.08 & 0.08 \\
\hline Pyrenees & France, Lac d'Aumer & PIUN & 42.51 & 0.09 & 2400 & $1324-2005$ & 682 & 82 & 173 & 0.97 & 0.57 & U. Büntgen & 0.14 & 0.09 \\
\hline Pyrenees & Spain, Cabanas & PIUN & 42.36 & 1.01 & 2400 & $1186-2007$ & 822 & 114 & 248 & 0.66 & 0.54 & U. Büntgen & 0.14 & 0.14 \\
\hline Pyrenees & Spain, Gerber & PIUN & 42.38 & 0.59 & 2400 & 924-2005 & 1082 & 200 & 209 & 0.80 & 0.54 & U. Büntgen & 0.14 & 0.19 \\
\hline Spain & Navafria II & PISY & 41.02 & -0.12 & 1630 & 1791-1992 & 202 & 28 & 152 & 1.48 & 0.64 & 1. Yuste Herederu & 0.16 & 0.05 \\
\hline Spain & Navafria III & PISY & 41.02 & -0.12 & 1525 & 1787-1992 & 206 & 24 & 150 & 1.67 & 0.69 & I. Yuste Herederu & 0.05 & 0.02 \\
\hline Spain & Penota & PISY & 40.67 & -0.33 & 1650 & 1763-1991 & 229 & 18 & 185 & 1.64 & 0.55 & $\begin{array}{l}\text { A. Fernandez-Cancio, M. } \\
\text { Genova Fuster }\end{array}$ & -0.07 & -0.04 \\
\hline Spain & Guadarrama, Iniesto & PISY & 40.80 & -3.98 & 1800 & $1749-1983$ & 235 & 39 & 174 & 1.52 & 0.55 & K. Richter & -0.20 & -0.01 \\
\hline Spain & $\begin{array}{l}\text { Guadarrama, } \\
\text { Camorca }\end{array}$ & PISY & 40.82 & -4.05 & 1550 & 1726-1983 & 258 & 27 & 138 & 1.30 & 0.63 & K. Richter & -0.16 & 0.02 \\
\hline Spain & Pedriza & PISY & 40.70 & -4.20 & 1650 & $1715-1988$ & 274 & 14 & 189 & 1.30 & 0.56 & $\begin{array}{l}\text { M. Genova Fuster, A. } \\
\text { Fernandez-Cancio }\end{array}$ & -0.04 & 0.20 \\
\hline Spain & Andrinal & PINI & 40.43 & -4.93 & 1500 & 1687-1989 & 303 & 12 & 221 & 1.18 & 0.58 & M. Genova Fuster & -0.05 & 0.07 \\
\hline Spain & Navafria I & PISY & 40.02 & -0.12 & 1900 & 1685-1992 & 308 & 31 & 188 & 1.31 & 0.53 & $\begin{array}{l}\text { I. Yuste Herederu, A. } \\
\text { Fernandez-Cancio }\end{array}$ & 0.26 & 0.05 \\
\hline Spain & $\begin{array}{l}\text { Guadarrama, Loma } \\
\text { de Noruego }\end{array}$ & PISY & 40.78 & -3.80 & 1950 & 1661-1985 & 325 & 26 & 186 & 1.44 & 0.54 & K. Richter & -0.03 & 0.05 \\
\hline Spain & Tajo & PINI & 40.87 & -2.13 & 1750 & $1610-1988$ & 379 & 16 & 205 & 1.24 & 0.62 & $\begin{array}{l}\text { M. Genova Fuster, A. } \\
\text { Fernandez-Cancio, A. } \\
\text { Perez Antelo }\end{array}$ & -0.04 & 0.39 \\
\hline Spain & $\begin{array}{l}\text { Guadarrama, } \\
\text { Rascafria }\end{array}$ & PISY & 40.80 & -3.95 & 1850 & 1599-1984 & 386 & 23 & 234 & 1.29 & 0.56 & K. Richter & 0.00 & 0.06 \\
\hline Spain & Puerto Llano & PINI & 37.82 & -2.95 & 1800 & $1585-1985$ & 401 & 26 & 323 & 0.95 & 0.67 & K. Richter & -0.22 & 0.19 \\
\hline Spain & $\begin{array}{l}\text { Puerto da } \\
\text { Navacerrada }\end{array}$ & PISY & 40.80 & -4.03 & 2050 & 1534-1976 & 443 & 22 & 183 & 1.51 & 0.49 & F. Schweingruber & 0.16 & -0.04 \\
\hline Spain & Valsaín (VA) & PISY & 40.79 & -4.04 & $1800-1900$ & $1554-2008$ & 455 & 74 & 328 & 0.86 & 0.52 & L. Fernandez Donado & 0.06 & -0.09 \\
\hline Spain & Peñalara $(R U)$ & PISY & 40.79 & -4.04 & 1850 & $1551-2008$ & 458 & 31 & 201 & 1.10 & 0.53 & L. Fernandez Donado & 0.09 & 0.04 \\
\hline Spain & Siete Picos & PISY & 40.87 & -4.10 & 1950 & 1527-1988 & 462 & 22 & 326 & 0.83 & 0.54 & $\begin{array}{l}\text { M. Genova Fuster, A. } \\
\text { Fernandez-Cancio }\end{array}$ & 0.17 & -0.06 \\
\hline Spain & Riscopol & PINI & 40.78 & -4.00 & 1600 & 1523-1988 & 466 & 24 & 241 & 1.08 & 0.68 & $\begin{array}{l}\text { M. Genova Fuster, A. } \\
\text { Fernandez-Cancio }\end{array}$ & -0.03 & 0.28 \\
\hline Spain & Torreton & PINI & 40.18 & -2.08 & 1500 & $1485-1988$ & 504 & 17 & 406 & 0.71 & 0.60 & $\begin{array}{l}\text { M. Genova Fuster, A. } \\
\text { Fernandez-Cancio, A. } \\
\text { Perez Antelo }\end{array}$ & 0.00 & 0.26 \\
\hline Turkey & Kirazli & PINI & 39.33 & 29.08 & 1650 & 1794-2002 & 209 & 38 & 175 & 0.91 & 0.65 & R. Touchan, M. Hughes & -0.29 & 0.41 \\
\hline Turkey & Aligalani & PINI & 39.27 & 28.85 & 1650 & 17712002 & 232 & 23 & 162 & 1.12 & 0.58 & R. Touchan, M. Hughes & -0.22 & 0.42 \\
\hline Turkey & $\begin{array}{l}\text { Kirazli, Aligalani, } \\
\text { Atalani }\end{array}$ & PINI & 39.28 & 28.93 & 1600 & $1771-2004$ & 234 & 79 & 173 & 1.02 & 0.57 & R. Touchan, M. Hughes & -0.29 & 0.45 \\
\hline Turkey & Kozlu Pinari & PINI & 36.65 & 32.20 & 1633 & $1586-2000$ & 415 & 25 & 295 & 1.10 & 0.52 & R. Touchan, M. Hughes & -0.25 & 0.19 \\
\hline Turkey & Around Alanya-Cevizli & PINI & 37.50 & 32.50 & 1500 & $1567-1995$ & 429 & 36 & 280 & 0.80 & 0.45 & Ü. Akkemik & -0.43 & 0.36 \\
\hline Turkey & Aziziye & PINI & 37.42 & 30.28 & 1601 & 1511-2001 & 491 & 35 & 204 & 1.38 & 0.52 & R. Touchan, M. Hughes & -0.25 & 0.40 \\
\hline Turkey & Circirtepe & PINI & 37.63 & 35.43 & 1500 & $1475-2001$ & 527 & 17 & 390 & 0.58 & 0.60 & R. Touchan, M. Hughes & -0.32 & 0.23 \\
\hline
\end{tabular}


tu Atalani_PINI

tu Kirazli PIN

tu Aligalani_PINI

tu Alanya-Cevizli_PINI

tu Aziziye_PINI

cy Plano platres (d)_PIBR

cy Plano platres (h) PINI

cy Armiantos_PINI

cy Troodos Moun._PINI

cy Chionistra_PINI

cy Armiantos_PIBR

tu Kozlu Pinari PINI

tu Circirtepe_PINI

al Thethi_PILE

al Lura PILE

al Partisan PILE

bu Vihren M.P.PIHE

gr Olympos Oros_PILE

bu Vihren F.S. PILE

gr Grevena PILE

gr Katara Pass_PILE

gr Scotida Forest_PINI

fr Pic d'Anie_PIMG

fr Roc de P. Blancas_PIMG

sp H. P. de Acher PISY/PIUN

fr Pic de sept Hommes_PIUN

sp Cabanas_PIUN

sp Gerber PIUN

fr Lac d'Aumer PIUN

sp Sobrestivo_PIUN

sp Port de Cabus_PIUN

fr Eyne_PIUN

sp Tajo PISY

sp Riscopol_PINI

sp Navafria II_PISY

sp Navafria III PISY

sp Puerto Llano PINI

sp Penota PISY

sp G.: Camorca_PISY

sp G.: Iniesto_PISY

sp G.: Loma de Noruego_PISY

sp G.: Rascafria_PISY

sp P. da Navacerrada_PISY

sp Navafria I_PISY

sp Valsaín PISY

sp Siete Picos_PISY

sp Peñalara_PISY

sp Andrinal_PINI

sp Pedriza PISY

sp Torreton_PINI

it Mt. Pollino L.T._PILE

it Mt. Pollino F.S._PILE

it Aetna PINI

683

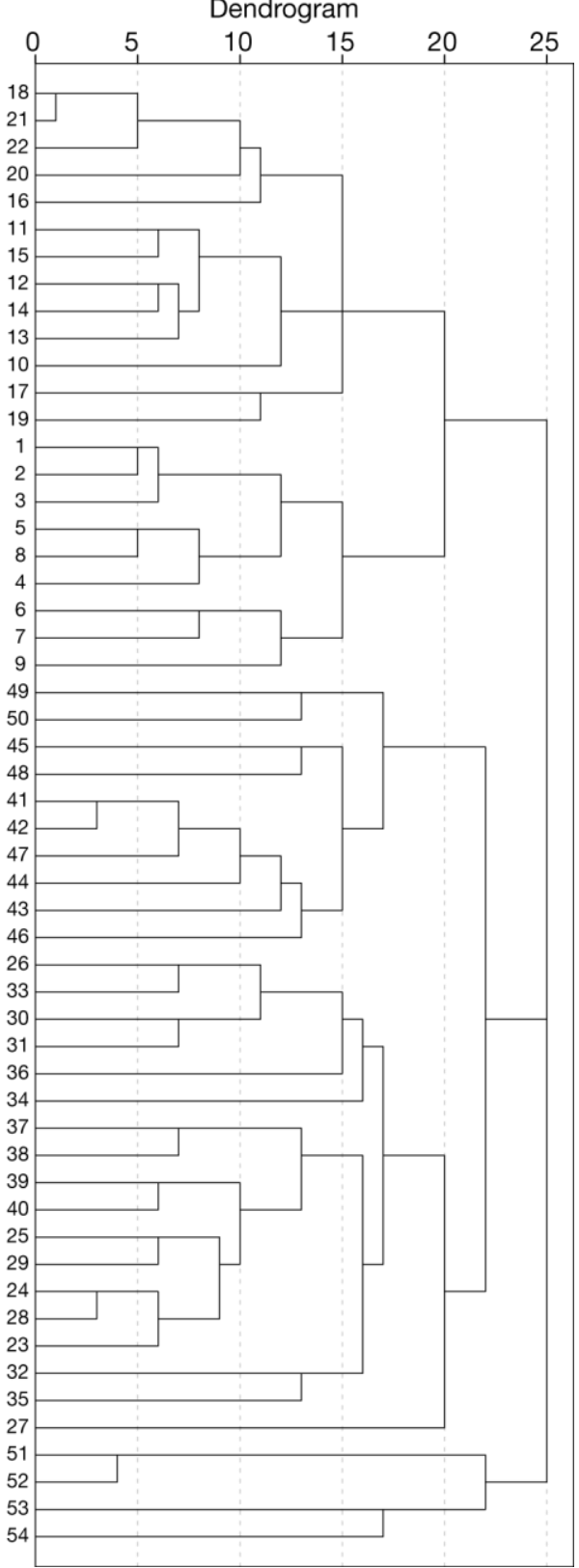

684 Figure S1. Dendrogram using average linkage between groups (Pearson correlation) for the

period $1862-1976 \mathrm{AD}$. 

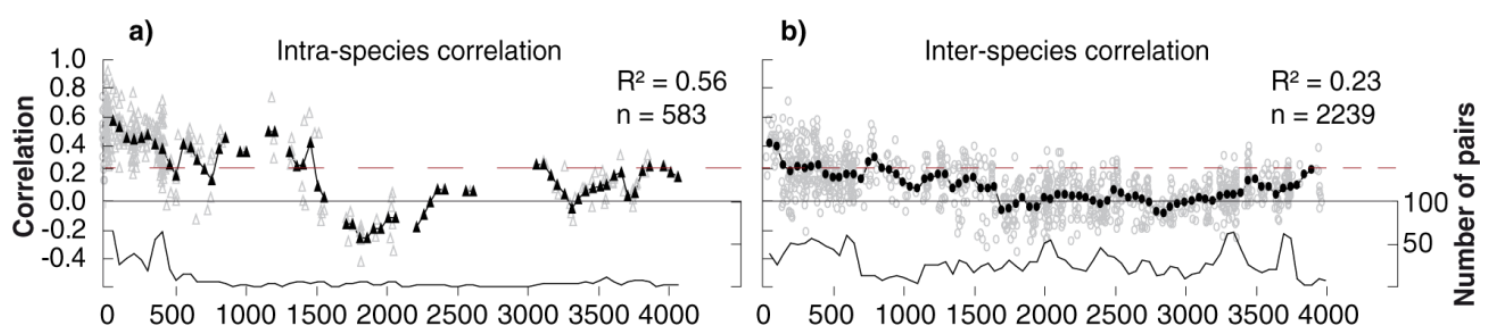
Distance $(\mathbf{k m})$

Distance $(\mathrm{km})$

688 Figure S2. Individual correlations (grey points and triangles) and their averages over $100 \mathrm{~km}$

689 distance classes lagged by $50 \mathrm{~km}$ (black points and triangles) and the corresponding 690 replication (black lines) for a) within species (grey triangles) and b) between species (grey 691 circles). Red dashed lines indicate the $99.9 \%$ significance level and $\mathrm{R}^{2}$ describes the explained 692 variance of a second degree polynomial regression model.

693 

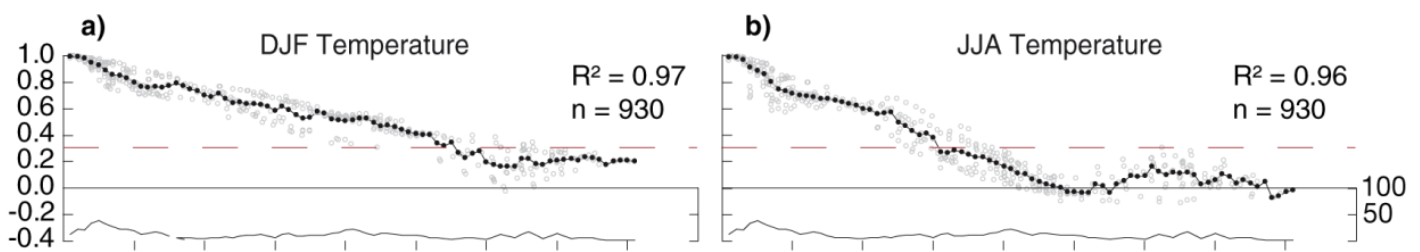

c)

DJF Precipitation

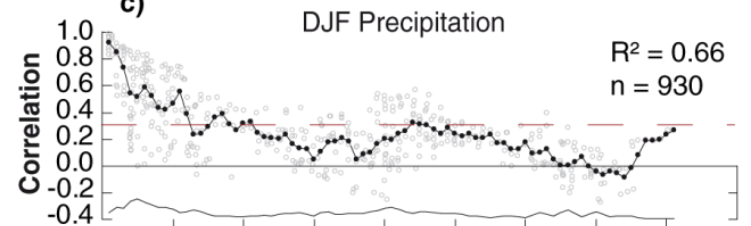

d)

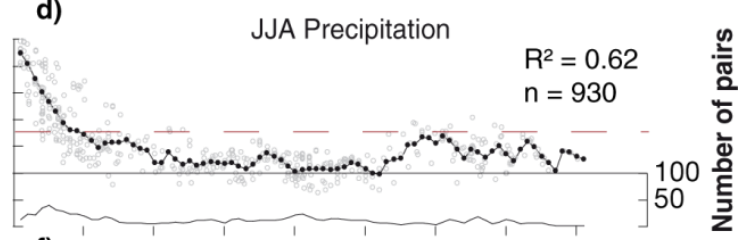

e)

DJF ScPDSI

f)

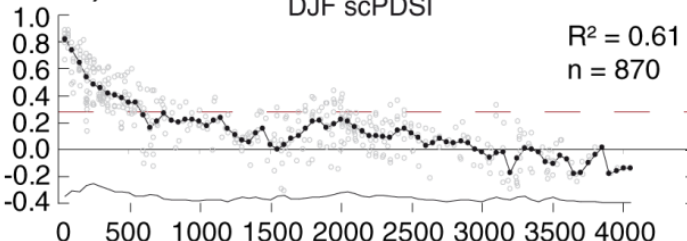

694

Distance (km)

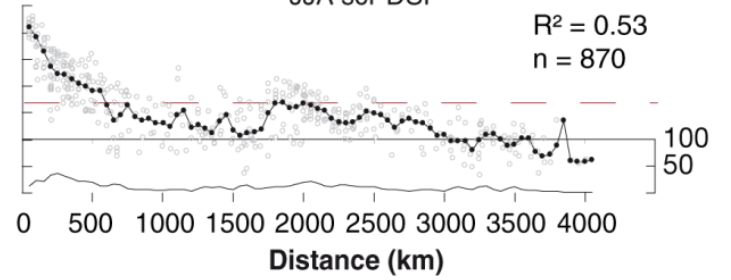

695 Figure S3. Individual correlations (grey points) and their averages over $100 \mathrm{~km}$ distance 696 classes lagged by $50 \mathrm{~km}$ (black points) and the corresponding replication (black lines) for a) 697 DJF and b) JJA temperature means, c) DJF and d) JJA precipitation amounts and e) DJF and f) JJA scPDSI values (CRU TS3.1). Red dashed lines indicate the 99.9\% significance level and $\mathrm{R}^{2}$ describes the explained variance of a second degree polynomial regression model. 


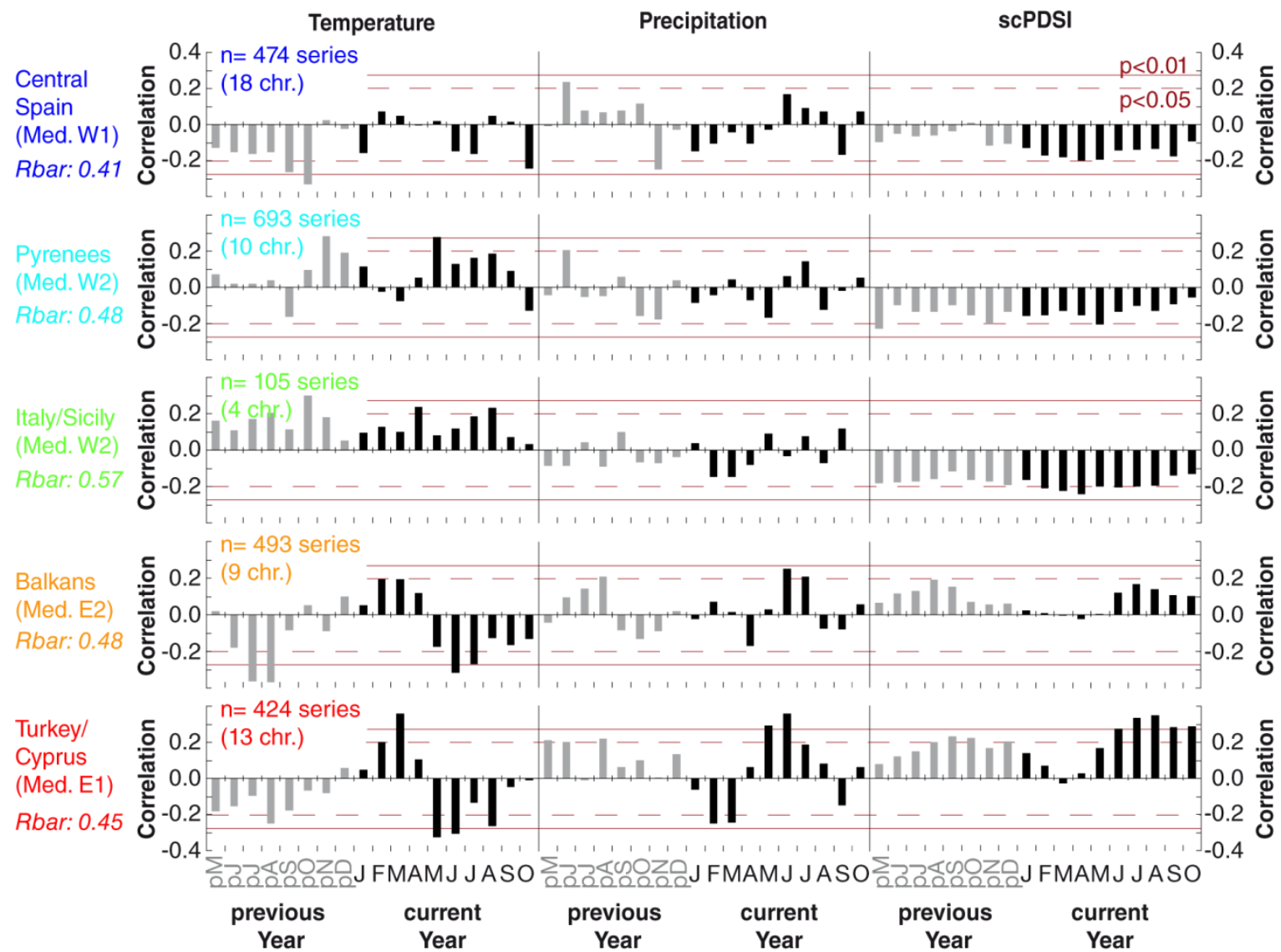

701 Figure S4. Growth-climate response patterns between PT 150yr spline detrended subgroup

702 chronologies and averaged gridded temperature, precipitation and drought data (CRU TS3.1)

703 calculated over the 1901-2002 periods using the 18-month window. Raw Rbar values are

704 shown for each PC subset and red (dashed) lines indicate the (95\%) 99\% significance level. 


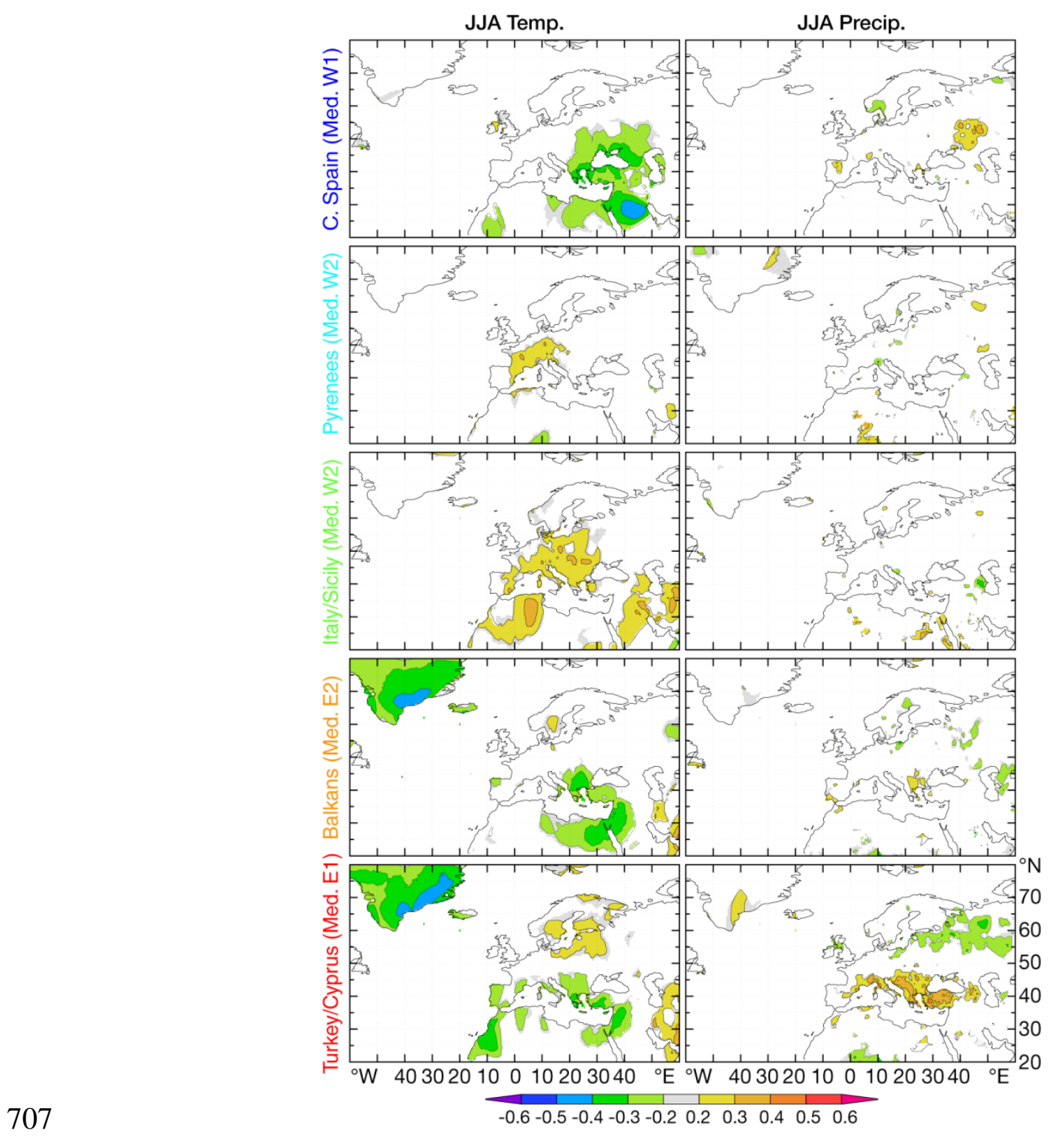

708 Figure S5: Spatial field correlations of sub-group composite TRW chronologies against JJA

709 temperature (left) and precipitation (right; CRU TS3.1) for the 1901-2002 periods. 